DOI: $10.1515 / \mathrm{abcsj}-2015-0001$

\title{
New Poetics of the Film Body: Docility, Molecular Fundamentalism and Twenty First Century Destiny
}

\author{
SUSAN FLYNN
}

University of the Arts, London

\begin{abstract}
Twenty first century film evokes a new topology of the body. Science and technology are the new century's 'sovereign power' which enforces biopolitics through bodies which, by virtue of being seen at their most fundamental level, have become docile surfaces. The film body is at once manipulated and coerced into an ethos of optimization; a thoroughly scientific and 'molecular' optimization which proffers 'normalization' and intimately regulated bodies. In the film bodies of this millennium, bodily intervention results in surveillance becoming internalized. Now the body is both a means and an end of social control. This essay applies the philosophies Michel Foucault and Nikolas Rose to twenty first century Hollywood film, elucidating a new tropos, a new film body/body of film.
\end{abstract}

Keywords: Hollywood, Michel Foucault, Nikolas Rose, science fiction, body theory, molecular science, biotechnology, disability

"A body is docile that may be subjected, used, transformed, and improved."

(Foucault 1991)

"Biology is not destiny but opportunity."

(Rose 2007)

\section{Introduction}

We inhabit an age of uncertainty; globalization, new communication technologies, the industrialization of war and the privatization of public 
resources are just some of the transformations affecting affective, economic, political and cultural systems. The current cinematic landscape is populated by a large number of films that articulate our fear of forces that may grow out of control. Transcendence (2014), The Maze Runner (2014), Elysium (2013) and Avatar (2009) are but a few of the popular films of our era. These films portray a world which is one of uncertainty, threat and impending disaster, due to a commoditized, competitive society. Contemporary Hollywood film is now often concerned with discourses of power, the promises of scientific advances and the possible optimization of the human body. Since the turn of the century, popular film has employed the pliable body to be the surface upon which the future of humanity is written; films which feature a docile body and a molecularization of man. The docile body is manipulated while it is observed at its most fundamental level. In this era of mass communication, the aberrant is seized upon to articulate all our fears and worries, and the solving of the 'problem' of being different is the ultimate goal to placate our worries. Reduced to a molecular sequence, 'difference' is fixable. Nowhere is this catharsis more obvious than in the film of the twenty first century. Hollywood celebrates normativity as the oil that greases the wheels of progress and thus utilises difference as a narrative tool. The body is used as the terrain on which the battle for power and autonomy is fought. Films replete with the threat of danger take us on a journey of cinematic escapism, which facilitates our release from 'imperfect' bodies, such as Robocop, 2014; Iron Man 3, 2013; Source Code, 2011.

In these films, the body is a site at which new technologies radicalize social control. Surveillance and domination become internalized as the body is colonized by power mechanisms, the body therefore becoming both a means and an end of social control. Pervasive power structures; multi-nationals and governments, actually become flesh as the bodily system and the capital system synchronise.

When Foucault wrote of the historic emergence of governmentality, this century had not yet begun. Yet his work resonates through the film depictions that capture our attention now, the films that articulate what Rose calls "emergent forms of life" (2007). In this millennium, popular 
film is the medium through which we imagine our past, our present and our future. Audiences, immersed in touch screen and instantaneous wireless interaction, eschew delayed gratification of the imagination. Meanwhile, in medical technology, stem cell research, computerised diagnostics, transplantation and gene therapy all point us to a future where technology and humanity collide.

This essay investigates what I term the compulsory optimization of Cinema's bodies in this century. I utilise popular film as a lens for the 'social imaginary', reflecting on the social meanings of 'imperfect' bodies, as they are defined in opposition to the supposed natural physical superiority of the 'norm'. The unoptimized body is deemed inferior; lingering at the parameters of social power. The meanings attributed to such bodies in popular film since the turn of the century are complicit in the compulsory optimization of our era; self-improvement by biomedical and biotechnical means is rendered the 'duty' of each individual, whether it is to restore functionality, beautify or normalize one's self. Popular media now suggest that the continuum of work now includes bodily selfimprovement to maximise one's worth in society. This century's characters enact that truly Foucauldian idea of citizenship; fit body equals fit nation.

The drive towards physical normalization inculcates a form of governmentality; beyond mere state control and irreverent of national boundaries, this control is the socially imagined perfect self of the twenty first century. The optimization of bodies in film, the intimate interference of biotechnology in forming 'beautiful' bodies reconstitutes ideologies of individualism and normalization. This essay draws on the work of Michel Foucault and Nikolas Rose, analysing the 'biological citizenship' that is arguably a requisite for twenty first century viewers and investigating the negotiation between non-normative bodies and the options available to them. Consequently this essay suggests that depictions of non-normative bodies in popular Hollywood films collude in both the notion of the body as a site of power and modern humanism's privileging of the fit masculine figure. The portrayal of optimization itself enacts a form of governmentality on non-normative audience bodies. However, were we to follow Hall's (1973) audience response theory, does it offer the audience a 
chance to reject that which they see on screen; does the representation of optimization in fact rupture the power of such governmentality, offering an enlightened view of corporeality as the last dominion of the self rather than the docile body enmeshed in power relations?

Glancing at contemporary films, this essay suggests that the molecularization of mankind now proffers a homogenous view of humanity; maximised men and women who tamper with their bodily 'imperfections' to optimize their opportunities. Contemporary films frequently address the complexities of this contemporary life, its relationship with medical science and the influence of new mass media, but since the turn of the century, the breakdown of man into his molecular elements the surveillance of the process of 'cure' has altered the cinematic landscape. The blurring of 'human' boundaries provides narrative material, which, by virtue of its timeliness, captivates audiences, because of the social ramifications of 'optimizing' life. Ontological intrigue is now bound up with discourses of 'fixable' bodies and the surveillance of this process.

\section{Foucauldian perspectives of the body}

Hollywood film since the year two thousand has been increasingly concerned with biotechnology's ability to invade and potentially improve the human body. In the wake of unprecedented shifts and advances in the biosciences and biotechnology, of which stem cell research and the Human Genome project are examples, Foucault's work on biopolitics is useful. National biopolitics, the 'fit body/fit nation' dyad is enacted in popular films such as The Maze Runner (2014), Elysium (2013) and Total Recall (2012). These films portray a dystopian future where bodily intervention and surveillance maximize man's potential to be a 'good' citizen. Furthermore, 'sub-optimal' bodies provide narrative opportunity for biotechnology to interfere with the human fabric. That the body is a site of power is not a new notion, but the films of this century enact a new poetics of the body, a new representation of subjectivity that is open to manipulation at the material and somatic level. The bodies of film now transform and transcend; social control is achieved through them in 
internal surveillance. The massive success of the science fiction genre and its use of surveillance and control of bodies illustrates that such subject matter captivates the social imaginary. Surveillance, once the gloomy Orwellian nightmare of the future, is now omnipresent in our filmic visions of the future. Transcendence (2014), The Maze Runner (2014), Total Recall (2012), Surrogates (2009) and Avatar (2009) explore the dangers of internalized surveillance and control. Avatar (2009), arguably the most successful film ever made, is based on the control of a body and the inner and outer surveillance. Furthermore, it features the appropriation of the body as a site of potential repair, proposing that biotechnology proffers new abilities to even the most 'damaged' bodies. Our social imaginary now sees 'damaged' bodies as matter that science and technology can recoup - as essentially pathological and in need of repair or transformation.

Using a Foucauldian perspective, it is possible to see how society has become predisposed to viewing non-normal bodies as pathological. Film makers seize pathological bodies to use as a "narrative prosthesis" (Darke 2010), an aberrancy used to drive the plot forward, to provide the 'crisis' which must be solved in the story. But from where do we get the seemingly natural urge to diagnose, classify and repair such 'abnormality'? Throughout the nineteenth and twentieth centuries, the scrutiny of bodies via medicine and science created a discipline of 'study', a disciplinary practice which allows or even encourages an examination of unusual bodies, giving a supposedly natural validity to curiosity about different bodies that is exemplified in film. Modern perceptions of the body may be effectively traced back to the late eighteenth century, when medical practice began to examine bodies in order to classify them.

In the eighteenth century, the fundamental act of medical knowledge was the drawing up of a map: a symptom was situated within a disease, a disease in a specific ensemble, and this ensemble in a general plan of the pathological world. (Foucault 1973: 13)

Foucault argues that the materiality of the body cannot be dissociated from the historical practices that objectivise it (Hughes and Patterson 1997: 333). The patient became the passive subject of the medical gaze, 
subjected to analysis and classification. Foucault maintained that this eighteenth century clinical discourse was the basis for a new regime of power, which he called 'biopower'. Foucault's biopower refers to the tendency of relatively recent forms of power/knowledge to work toward an increasingly comprehensive management of life; both the life of the person and consequentially the nation. In The Birth of the Clinic (1973), Foucault argues that the dividing practices of the nineteenth century clinics affected the treatment of the body by professionals. Categorization, segregation and manipulation of subjects were objectifying procedures, through which subjects become attached to a personal and social identity. Foucault considered normalization to be the cornerstone of biopower. Normalizing technologies (practices of bodily reconstruction, analysis and rehabilitation as well as self-help groups, fitness regimes etc.) perform disciplinary functions, encouraging subjects to identify themselves in ways that make them governable. Through the work of Foucault, then, it is apparent that from the beginnings of modern medicine, classification and governability have gone hand-in-hand. The scientific classification of persons has been seen as the primary determining factor rather than their socially-created identity.

Foucault's work on medicine has relevance to studies of twenty first century film, because of his examination of the power relations which, constructed historically, lend acceptability to examination of 'other' bodies. Foucault's interest in power is highly relevant to contemporary film then; if we look at key texts and ask whose interests they serve and what relationships of domination do they maintain, a power system becomes apparent whereby the institutional power structures of Hollywood are maintained. Foucault saw representations as productive of meaning and so films' political effectiveness lie in how they represent, rather than in what they represent. In this vein de Lauretis wrote of film "as a set of regulated procedures, mechanisms and techniques of reality control" (Lapsey \& Westlake 1988: 20). As such, applied to film analysis, the realities that films construct may be seen as historically contingent, dependent on the time, place and power structures. In this vein, the practice of surveillance in twenty first century film is indicative of modern practices of surveillance and control. The panopticism of this century, 
which is evident in policing practices of today's Western world; being 'caught on camera'; manifests as a disciplinary mechanism of the psyche. Being seen, then, becomes being controlled just as being 'under the radar' equates to freedom of movement and human freedom in all of its manners. Contemporary Hollywood knits this fear into its narratives, the repulsion at panopticism often providing narrative opportunity. In The Maze Runner (2014) the 'glade' is a panopticon par excellence, and the greatest motivation of its inhabitants is provided by the exposing of the panopticon system. Grasping that they are effectively 'lab rats' watched over by a powerful scientific elite, the inhabitants are inspired into action by the realization that they are under constant surveillance. Attempting to flee the glade, they are duped into believing their oppressors have been killed, but this is yet another manipulation. In this film, biopower is directed at the gladers' bodies and their potential to resist the 'Flare' pandemic. Biopower coalesces around the group of boys in their organizational structure. The hierarchical structure forms disciplinary practices that divide the boys into units (cooking/fighting/mapping) and subject the boys to calculated training. Power "reaches into the very grain of individuals, touches their bodies and inserts itself into their actions and attitudes, their discourses, learning processes and everyday lives" (Foucault 1980). Their individual bodies thus become docile, that is, they may be transformed, molded and improved, resulting in a disciplined subject who is both efficient and productive. The boys observe themselves as well as being observed by an unseen power; both within and outside the glade, they are therefore subject to normalizing judgments. Exterior and interior control intersect, the individual body becoming a surface upon which history is written, and the topology of the glade merging with the mind until the question "Is this the beginning of the Maze or the end?" becomes apocryphal.

In many recent blockbuster films, the body is politicized by its use as a discourse of power; the tussle for subjectivity, for potency as an active subject, becomes a power play. In this sense, the theories of Foucault are highly relevant; they assist an understanding of the body as a thoroughly politicized space, simultaneously imprinted by history and in constant flux. The histories and power structures that are involved in 
creating current social conditions, what Foucault calls 'biopower', may be seen on the Big Screen of the modern Hollywood blockbuster; indeed its agenda is employed in many of the popular narratives, though it may be quietly encoded.

Biopower is the proper name for the emergence and integrated exercise of both a technology of discipline, which produced docile bodies, and the normative regulation of populations; it takes life as the object of its exercise. (Anders 2013: 3)

Foucault's work is used here as a lens through which relationships of power and dominance have become naturalised. From the seventeenth century, power over life evolved in two forms; firstly, the body as a machine which is disciplined and optimized, made useful and docile. The second was the species body, which inculcated all the mechanics of life, birth and death, health, longevity and all the conditions that cause these to fluctuate. The management of these conditions and regulatory controls formed the biopolitics of the population (Foucault 1991). In this millennium we see biopower played out on the big screen as institutions of power regulate disease (The Maze Runner, 2014; World War Z, 2013; Contagion, 2011).

In modern societies people are no longer controlled predominantly through the overt exercise of sovereign power, but rather, by selfregulation: "Bio-power extends the mechanisms of disciplinary societies through an intensification of individuals' relationships to themselves and their own self-governance" (ibid.). When popular films such as The Maze Runner, Transcendence, Elysium and Avatar extoll the virtues of biotechnology, they subtly collaborate with biopower; suggesting that we police our own bodies, and seek to 'optimize' them. These twenty first century films illustrate this biopower in the fabric of the human society and the interactions therein; the surveillance of characters from outside forces and indeed the self-surveillance speak of a body that is constantly manoeuvred, jostling with its own identity and in the service of dominant power structures. This is effectively a body made docile. Surveillance, in these films, is both hierarchical and normalizing; it functions as a disciplinary practice, wishing to first examine, then to correct. 
Surveillance, then, is a tool of the "societies of control":

Societies of control extend and intensify the tactics of discipline and biopower (by linking training and surveillance to ever-more-minute realms of everyday life), they also give birth to a whole new form. (Nealon 2008: 68)

\section{Medicine and the dis-abled bodies of film}

Foucault's work illustrates that the birth of medicine and its power was concurrent with the distinction between 'normal' and pathological. From the beginning of modern medicine, medicine created itself as "the rational repository of truth with respect to the biological integrity of individuals and populations" (Hughes 2012). This distinction forms the binary between normal and abnormal, the framing of the 'dis-abled', the 'invalid' who is not fully constituted as a normal human being. The clinical distinction, based on a medical diagnosis, lends authority to the stigma that is created.

With the advent of the distinction between the normal and the pathological, it becomes possible to 'see' impairment and to 'say' disability; in addition, disability becomes discursively constituted as a physical or moral deficit. ... Medicine reinvents itself as the rational repository of truth with respect to the biological integrity of individuals and populations. (Hughes 2012: 82-83)

Thus from a Foucauldian perspective, society became predisposed to view disability as a pathology. The result is that disabled people have become the object of disciplinary power, people with impairments are thus produced as disabled subjects, about whom decisions are made or representations are made in the case of film. In this century, 'sub-optimal' bodies are not just the 'dis-abled' bodies, but those which are not achieving maximal potential. According to Foucault, the body is acted upon by various power structures, power reaches into individuals through supervision and surveillance and the body is 'docile' (Hughes 2012: 86). Fundamentally Foucault saw the subject as a social construction, not a given. Since power is inseparable from knowledge, the medical gaze is a 
technology of power, which aids in the construction of the 'sub-optimal' subject. Thus Foucault exposes the creation of the conditions which have allowed ideologies of optimization to thrive. Twenty first century film has relied on these ideologies, representing less-than-perfect bodies as pathological and their characters as subjects who are acted upon, supposedly with their best interests at heart. The creeping of power structures into the body of the person speaks of a society of control in which power is internalized. Issues of identity, thus, become embroiled in power dynamics. The individual's particular attributes are thus exposed to scrutiny which is made to seem just and fair.

In Avatar (2009) the scrutiny of the main character and later the intervention, objectify the person, making his body the docile surface upon which this particular history will be written. Sully (Sam Worthington) is impaired, and as (under a Foucauldian perspective) normalizing judgement constitutes impairment as a deficit, so Sully has an in-valid social position. The subtle suggestion of optimization necessarily includes intervention and control and so intervention is welcomed. Avatar's vision of the future is replete with reformulations of culture, work and technology. The intersection of physiology and technology in Avatar result in a quintessential postmodern fantasy of instantaneous transmission, a radicalization of mind and matter and of organic and mechanical. This raises questions about how we see the future of disability and its representation, how we align our hopes for a medically and scientifically advanced future with the reality of imperfect bodies. In the dystopian future of Avatar, the disabled body is viewed as waste that a military industrial complex can recoup. Disposable military bodies are continually sacrificed during conflicts in the film. The disabled main character, Sully, is given the ability to acquire a prosthetic alien-soldier body not as compensation for his disability but in spite of it - his genomic capital as the twin of his dead scientist brother makes him the only possible match for the cloned body, a technology far more expensive than his own 'defective' body. This disturbing disruption of bodily integrity and mental privacy upsets the concept of personal identity but also commodifies the human body. In this case, a disabled one is 'colonized' by the military corporation, becoming 'whole' through its surrender to the 
colonizing forces. The transcendent qualities of CGI and biotechnology here pose a troubling solution to the delicate human organism. The film's vision of the future as enveloped in genetic fundamentalism is thus a frightening development of the current fascination with genomic capital. This fetishizing of DNA has a dangerous consequence for disability; it suggests that 'defective' genes which lead to an impairment may be screened out, leading to a dehumanization of the individual where he or she is reduced to a quantifiable set of molecules.

In contrast, Pandora's network-culture decides what peripherals or hardware can interface with each other, regulating what organ can plug into what port, just as the planet's animals are the peripherals or hardware that the natives employ as prosthesis. In Pandora, the natural world is considered as a single living organism, as opposed to the capitalist agenda of Earth, with the competing interests of individuals and corporations. The collapse of boundaries between abled and disabled, human and machine is representative of film's move towards a Baudrillardian postmodern uncertainty. In this age of biotechnology, cinema repeatedly illustrates corporations which are now drawn into this paternalistic ethos. Biotechnology's ability to reconstitute normality is a heavily loaded anthropophagic strategy. The Maze Runner (2014), Robocop (2014), Iron Man 3 (2013), Elysium (2013), In Time (2011), Repo Men (2010) and Surrogates (2009) are films in which corporations have the power to give life but also to take it away. The loss of autonomy and self-determination that ensues for the disabled characters is eclipsed by the characters' frenzied fear of losing their new-found 'normality'. These films differ from similar films of the last century, for example Gattacca (1997), as their narratives depend on surveillance, the twenty first century's defining filmic feature, which depicts powerlessness in the face of institutions of power, while expressing the sinister voyeurism of modern technologies. Such technologies, in the hands of institutions of power, may be seen to enact a sovereign power- while biopolitics today is seen as largely positive and productive (Cadman 2009), films express concern that the power to 'give life' lies in the hands of a powerful few. "Subsequently, we are all, by virtue of being biopolitical animals, at risk of becoming forms of bare or naked life subject to a sovereign decision" (Cadman 2009: 134). 


\section{Film, power and capitalism}

Film criticism, in particular semiotics, has long accepted that film is like a language and that we read a film, not just by the dialogue but by constructing meanings based on the sum of what we see in the frame (Monaco 2009). Film's ability to subliminally reinforce the 'universal truths,' the prevalent ideologies, is therefore a powerful force in reconstituting culture: "It is not because the cinema is language that it can tell such fine stories, but rather it has become language because it has told such fine stories" (Metz 1974: 47). These stories, however, may provide misleading or even dangerous interpretations of various groups in society. They may accentuate certain power structures and as such, be political vehicles.

The main tradition of American criticism has preferred to see films not so much as products of specific authors but as evidence of social, cultural, and political currents...much of recent theory sees film as a political phenomenon, albeit abstractly rather than practically. (Monaco 2009: 475)

In Repo Men (2010), the recipients of technological organs are customers; the ultimate consumers, who literally need the product to live. Tracked through their tech-organs, they are compelled to pay the corporation or have their organs forcibly removed and so they are forced to self-police. This novel politics of life, a politics of survival, enacts the link between the bio-economy and biological body as a site for the government of individuals. Moreover, this narrative speaks of new sets of social relations where rights to cure merge with capitalism and the now complex relationships of donor/recipient. In the last century's films, medical science attempted to cure, to re-establish vitality and to prolong life. This century's films, however, attend to these new sets of relationships and the threshold of humanity which is destabilised by biotechnology.

\section{Nikolas Rose and the politics of the body}

When we consider the body which occupies twenty first century film, we 
consider a deeply politicized space, in that post-structuralist sense, as film bodies enact difference or docility. In our cultural imaginings, and consequently in film, bodies are now 'open' to intervention. The twenty first century has brought a multiplicity of life-optimizing technologies.

These new forms of life, these new ideas of what kind of persons we are and could or should become, are emerging at the multiple intersections between the imperatives of the market and the drive for shareholder value, the new imaginations of the body and its processes. (Rose 2007: 105)

The new imaginations of the body "must be understood as hybrid assemblages oriented towards the goal of optimization" (Rose 2007: 17). The popular films of this century enact these new imaginations of the body, as they depict its need of biotechnical intervention, its transformation and its transcendence of the human/machine boundary. This is played out most spectacularly in Transcendence which places 'life' somewhere at the boundary of human/machine, reducing life to a series of codes.

Biology is now inextricably linked with information technology and has become in its own right a science of information. It is not interested in man, but rather in his elementary components, apparently without concern for the negative consequences of this conception of the human, given that it dissolves the subject, and perhaps even the human condition itself. (Le Breton 2004: 2)

Life is now seen as a sum of information; reducible to numbers, our humanity is calculable, alterable and reducible. This century's vision of life is at the molecular level; images of coding sequences and DNA form the contemporary view of life itself, privileging the order and sequence of the imagined pattern of 'life'. Scenes of computerized diagnostics and highly complex gene sequencing feature in many of this century's science fiction narratives, as well as contemporary crime dramas where 'proof' is envisaged at the molecular level, for example the 'scientific' close-ups of the C.S.I. television franchise. This view of 'molecular' life also opens up the human to scrutiny; 'flaws' become disjunctures where intervention is necessitated and ontology becomes mediated. 
"[M]olecular biopolitics" now concerns all the ways in which such molecular elements of life may be mobilized, controlled, and accorded properties and combined into processes that previously did not exist. At this molecular level, that is to say, life itself has become open to politics. (Rose 2007: 15)

This molecular bio-politics is enacted on screen, producing rational methods of creating 'docile' bodies. Humanity itself is reimagined by genetic information, as opposed to past times when natural history had a static, non-temporal classification for living things (Cadman 2009). Current cultural representations utilise this vision of humanity, creating narratives for audiences to play out this catharsis. Our new vision of the body is predicated on our view of biology as pliable and fixable.

Genetic information no longer necessarily passes in a one-way, linear path of descent from one generation to the next. Rewritten as information, message, code or sequence, the gene becomes newly flexible as it also becomes differently (re)productive. (Franklin 2000: 190)

In Transcendence we see that life is reducible to a series of codes which may be replicated to make a virtual life. It is the 'duty' of the widow Evelyn (Rebecca Hall) to recreate her genius-husband Will (Johnny Depp) for the sake of humanity's progress. After his death, Evelyn uploads Will's consciousness in the quantum computer they have developed. In his virtual form, Will connects with the internet as he 'needs more power', his now vast intelligence making him a technological sentient entity with limitless powers. The human has now become a series of codes; but the tale is cautionary as Will remotely connects to humans and controls their minds and bodies once they have been subjected to his nano-particles. The technological Utopia he promised becomes a true control centre. Were we to ask what anxieties does this film address, we could not but answer that the new hybrid assemblages of modern biology cause us to question contemporary biopower.

Life is problematic today because new understandings and new technologies that are involved in giving it a form are producing results that escape the philosophical self-understanding provided by both the classical world and the Christian tradition. (Rabinow 1999: 16) 
The forms of governmentality that now concern audiences appear to be biotechnological and scientific rather than national. Biotechnical advances seem to reshape our vision of the future, where dangers reside not in foreign governments but in extensions of the powers of expertise.

\section{Normalization and nation}

Popular film of this century seizes traditional 'medical knowledge' and transforms it into the molecular; the act of seeing disease/ disability leads 'naturally' to intervention. Medical knowledge incurs a duty to repair or improve. Just as biopower extends the mechanisms of society through the individual's relationship to himself, by creating a 'duty' to conform and optimize, so too does the contemporary film character bow to the 'greater good' by optimization. In the attempt to 'normalize' any renegade genes, especially in 'contagion' films, humans are reducible to sequences, which may or must be corrected in order to save mankind. Normalization must be completed at the genetic level.

The norm consequently lays claim to power...Canguilhem called it a polemical concept... the norm brings with a principle of both qualification and correction. The norm's function is not to exclude and reject. Rather, it is always linked to a positive technique of intervention and transformation, to a sort of normative project. (Foucault 2003: 50)

Just as the birth of modern medicine brought a medical profession "invested, at the level of man's bodily health, with powers similar to those exercised by the clergy over men's souls" (ibid.), so does the molecular fundamentalism of this century invest the scientist (at least in our cultural imaginings) the power to interfere with the very fabric of the human body at its most basic level. The authority of this scientific knowledge is lauded in popular culture, film is populated with intelligent 'lab coats' who have the power to create, sustain or alter life. Critically, however, these filmic interventions to optimize life are administered in ways that reinforce relationships of control. Institutions of power, corporations and governments, maintain control of the populace through their control of science and technology (Robocop, 2014; Source Code, 2011; Repo Men, 
2010; Surrogates, 2009). Citizenship includes self-optimization in that very Foucauldian dyad of fit body/fit nation. Self-correction and selfenhancement are now portrayed as the duty of the twenty first century citizen. Modification is seen as increasingly 'natural' and essential for the future.

This biological ethopolitics - the politics of how we should conduct ourselves appropriately in relation to ourselves, and in our responsibilities for the future - forms the milieu within which novel forms of authority are taking shape. (Rose 2007: 27)

Medical technologies have become technologies of life; a way of life that is intrinsic to our vision of our future. In contemporary popular film we see our future selves as pliable beings; as modifiable and as improvable. Scientific intervention is seen to promise cures, transplants and genetically modified 'spare parts' such as Repo Men. Films increasingly suggest we may stay home and live vicariously through 'engineered selves', virtual selves, or Surrogates (2009). Science fiction goes so far as to suggest a future populated with clones such as The Island (2005), Never Let Me Go (2010). The sentience of man-made organisms fascinates us and speaks of a lingering fear of 'meddling' with nature.

\section{Ruptures in the vision of progress}

These films suggest, somewhat tentatively that these 'advances' will bring new forms of inequality, new forms of exploitation. Here we may conceive of a rupture in the 'preferred meaning' of film. Following Hall's (1973) audience response theory, the audience has a chance to reject that which they see on screen; the representation of optimization may in fact rupture the power of such governmentality, offering an enlightened view of corporeality as the last dominion of the self rather than the docile body enmeshed in power relations. At the concluding scenes of Surrogates the characters chose fallible, messy human life over safe, clean surrogate life; the power over the body thus representing democracy. Transcendence also ends with the vagaries of unoptimized life eventually being celebrated; the final shots of sunflowers encapsulating the fleeting and delicate nature of 
'real' life:

[T] he 'dark side' of our contemporary biopolitical contestations is not that they are potentially murderous, but that they potentially engage with and produce inhuman lives. (Cadman 2009: 153)

The notion of "design on demand" (Franklin 2000), the possibility of improving any aspect of our human bodies now plays out in film narrative in a deeply foreboding manner.

\section{Conclusion}

Film narratives of the twenty first century have evolved to correspond to scientific advances and the new 'hybrid assemblages' of life itself. Films now enact a new tropos of the body; they display a compulsory optimization where self-regulation, self-preservation and selfimprovement are the duty of every individual. Scientific intervention, once targeted at frailty, is now directed at enhancement of capacities. Narratives now enact circuits of transformation where medical diagnosis leads to technical intervention at the biological and molecular level. When Rose wrote that "the vitality of the body has become increasingly open to machination" (2007: 254) he may just as well have been predicting the narrative fascinations for this generation of film.

When popular contemporary films extoll the virtue of biotechnology, the largesse of science and all they propose to offer, they subtly collaborate with biopower, suggesting that we police our own bodies and optimize our potential. However, the surveillance which is depicted in contemporary narratives may remind us that the body is constantly manoeuvred, jostling with its own identity and in the service of dominant power structures. Is it possible that such depictions might open up a space for nostalgia? That those pre-biotechnology bodies might represent human dominion over the human body? Might not this at last be the revolution of the biotechnology era, when we chose fallibility over optimization? The creeping of power structures into the body of the person speaks of a society of control in which power is internalized. This young century's films may yet turn to a repulsion of internalised power 
and a celebration of the fallibility and fragility of life.

\section{Works Cited}

Anders, A. "Foucault and the 'Right to Life': From Technologies of Normalization to Societies of Control." Disability Studies Quarterly 33.3 (2013): 1-18.

Cadman, L. "Life and Death Decisions on Our Posthuman(ist) Times." Antipode 41.1 (2009): 133-156.

Darke, P. "No Life Anyway: Pathologizing Disability on Film." The Problem Body. Ed. by S. Chivers and N. Markotic. Ohio: The Ohio State U.P., 2010. 97-101.

Foucault, M. Abnormal: Lectures at the College De France 1974-1975. Trans. Graham Burchell. New York: Picador, 2003.

Foucault, M. The Foucault Reader. Ed. by P. Rabinow. London: Penguin, 1991.

Foucault, M. The Birth of the Clinic: An Archaeology of Medical Perception. Trans. A.M. Sheridan. London: Routledge, 1973.

Foucault, M. "The Eye of Power." Power/Knowledge: Selected Interviews and Other Writings, 1972-1977. Ed. by C. Gordon. Brighton: Harvester, 1980.

Franklin, S. "Life itself: Global nature and the genetic imaginary." Global Nature, Global Culture. Ed. by S. Franklin, C. Lury, and J. Stacey. London: Sage, 2000. 188-227.

Hughes, B. "What Can a Foucauldian Analysis Contribute to Disability theory?" Foucault And The Government of Disability. Ed. by S. Tremain. Ann Arbor: U. of Michigan P., 2012. 78-92.

Lapsey, R. and M. Westlake. Film Theory: An Introduction. Manchester: Manchester U.P., 1988.

Le Breton, D. "Genetic Fundamentalism or the Cult of the Gene." Body \& Society 10.4 (2004): 1-20.

Metz, C. Film Language: A Semiotics of the Cinema. Chicago: U. of Chicago P., 1974.

Monaco, J. How to Read a Film. $2^{\text {nd }}$ ed. Oxford: Oxford U.P., 2009.

Nealon, J. Foucault Beyond Foucault: Power and its Intensifications since 1984. Stanford: Stanford U.P., 2008.

Rabinow, P. French DNA Trouble in Purgatory. Chicago: U. of Chicago P., 1999.

Rose, N. The Politics of Life Itself. Princeton: Princeton U.P., 2007.

\section{Filmography}

Avatar. Dir. J. Cameron. U.S.A.: Twentieth Century Fox Film Corporation, 2009. Contagion. Dir. S. Soderberg. U.S.A.: Warner Bros., 2011.

Elysium. Dir. N. Blomkamp. U.S.A.: Machinist Pictures, 2013.

Gattaca. Dir. A. Niccol. U.S.A.: Columbia Pictures, 1997. 
Never Let Me Go. Dir. M. Romanek. U.K.: Fox Searchlight Pictures, 2010.

Repo Men. Dir. M. Sapochnik. U.S.A.: Universal Pictures, 2010.

Robocop. Dir. J. Padilha. U.S.A.: $20^{\text {th }}$ Century Fox, 2014.

Source Code. Dir. D. Jones. U.S.A.: Summit Distribution, 2011.

Surrogates. Dir. J. Mostow. U.S.A.: Walt Disney Studios Motion Pictures, 2009.

The Island. Dir. M. Bay. U.S.A.: Dreamworks Distribution, 2005.

The Maze Runner. Dir. W. Ball. U.S.A.: $20^{\text {th }}$ Century Fox, 2014.

Total Recall. Dir. L. Wiseman. U.S.A.: Columbia Pictures, 2012.

Transcendence. Dir. W. Pfister. U.S.A.: Warner Bros. Pictures, 2014.

World War Z. Dir. M. Forster. U.S.A.: Paramount Pictures, 2013. 